thirty years. She noted at the time of the Exhibition that the portrait was then badly faded.

Mr. and Mrs. Avery reside in Nevada, Missouri, where Mr. Avery was Assistant to the President of Cottey College. Both of the Averys are Drake graduates; Mr. Avery graduated in 1928 and Mrs. Avery in 1930. During their college days they often visited the Department of History to view the Lucas portrait.

The daguerrotype, which is housed in its original case, will be carefully wrapped and stored in a vault here in the Historical Building. Soon a qualified photographer will be contacted and copies of the daguerreotype will be made and displayed. The original daguerreotype would be damaged by continuous exposure to harsh light and for this reason, only prints of the daguerreotype will be displayed.

\title{
AN EARLY SETTLER IN IOWA: WESTWARD EXPANSION IN MICROCOSM
}

\section{by Dr. Bertha R. Leaman Haverford, Pennsylvania}

Dr. Leaman is a Modern European Historian with both advanced degrees from the University of Chicago and a year of study at the Sorbonne. Now retired from college and university teaching, Dr. Leaman is busily occupied with work on Franco-American relations for which she was recently awarded a grant by the American Philosophical Society.

The settlement of the State of Iowa was part of the relentless pull which produced the westward migration of the American people. Prior to 1833 there were comparatively few settlers in the State of Iowa. In 1832 the Black Hawk Purchase Treaty was signed and with it came the real beginning of the white settlements there. At an earlier date furs had lured the trapper, then the discovery of veins of lead in the hills and bluffs around Dubuque had drawn the adventurous, but it was ultimately the fine quality of the land which drew those who came to Iowa to make it their home. 
During the winter of 1842 the government announced that the lands obtained from the Sauk and Fox Indians were to be opened to settlement. Settlers had been coming into Eastern Iowa consistently since 1830, "now began such a migration as had never before been witnessed. . . . . This great exodus from the Eastern states continued unabated for several years, reaching its height during 1854-55."

Having started late, Iowa's population grew rapidly. From 1850 on, the influx of immigrants and settlers reached enormous proportions. Turner calls it an extraordinarily quick growth, saying that between 1836 and 1840 the population of Iowa approximately doubled every two years. ${ }^{2}$ And another observer says: "The mighty migrations into our state during the $1840 \mathrm{~s}$ and the 1850 s were so tremendous that their volume staggers even the most sluggish imaginations. Accounts of them leave me awed." ${ }^{3}$ He adds that he was "prideful, too, as my comprehension begins to grasp just how titanic, purposeful and history making was that great flood of determined men and women, which, during those years, so resolutely and painfully made its way here., ${ }^{4}$

In 1840, two years before the attainment of statehood, the population was 43,000. "In May, 1942, the newspapers of St. Louis announced that during the first three months of that year 529 steamers had arrived in the harbor of St. Louis with more than 30,000 passengers destined for Iowa. The causes of this rapid filling-up of the new territory were: the good soil, the fine climate, and the discovery of lead mines in the neighborhood of Dubuque." ${ }^{5}$ Between 1840 and $1850,150,000$ people moved to Iowa and the next decade saw a flood of immigrants. ${ }^{6}$

\footnotetext{
${ }^{1}$ Carl S. Foster, Heritage of Guthrie County (Northland Press, Waseca, Minnesota, 1962--), p. 24.

${ }^{2}$ Frederick Jackson Turner, United States, 1830-1850 (New York, Holt, 1935), p. 258.

${ }^{3}$ Foster, op. cit., p. ii.

${ }^{4}$ Ibid.

${ }^{5}$ Albert B. Faust, The German element in the United States (New York, Houghton Mifflin, 1909), p. 462.

${ }^{6}$ Bruce E. Mahan, "The way to Iowa," The Palimpsest, II, No, 10 (October, 1921), 301ff. See also Cardinal Goodwin, "American occupation of Iowa," Iowa Journal of History and Politics, 17 (1919), 83ff.
} 
In the decade between 1850 and 1860 the influx reached tremendous proportions. Prior to the mid-1850s these immigrants came in wagons, drawn by horses or oxen, but as they trudged along a competitor was coming into existencethe railroad. By 1855 it had really entered Iowa. The Rock Island had reached the Mississippi in 1854 and by 1856 it had puffed its way to Iowa City.

A large German element also helps to explain the invasion of the state. The height of the German immigration of the nineteenth century, prior to 1880 , was between the years 1850 and 1854. The largest percentage of the people came to the mid-Western states of Illinois, Wisconsin, Michigan, Minnesota and Iowa. ${ }^{7}$ "In 1855-56 was the great land rush in Iowa, which seemed to be the Eldorado to the people of Indiana, Illinois and Ohio. Guthrie County received her share of them." Like native Americans, many Germans were also drawn to Iowa from Missouri and Illinois for the new lands there. ${ }^{9}$

These were years of continuous and almost incredible expansion. ${ }^{10}$ By 1850 the formative period of the state was over and settlers who came after that time found an organized and going state. The structural formation of the state had been established and it was now ready for the growth and development of its social and economic order.

The roots of one of the families that helped to develop Iowa reach back to the beginning of the settlements in Penn's Woods. While William Penn was trying to induce people to come to his new plantation on the Delaware, a group of Huguenots in France were trying to find a place to go. Since 1598 the Edict of Nantes had given religious toleration to French Protestants. When, in 1685, Louis XIV revoked this Edict these skilled middle class craftsmen were persecuted. Penn did some effective advertising in the Huguenot country, indicating that in Penn's Woods the forests were full of game,

${ }^{7}$ Faust, pp. 461f.

${ }^{8}$ Past and present of Guthrie County, Iowa, together with biographical sketches of many of its prominent and leading citizens and illustrious dead (Chicago, Clarke, 1907), p. 92.

${ }^{9}$ Faust, p. 462 .

${ }^{10}$ Cardinal Goodwin, loc. cit. 
the rivers teeming with fish, the climate excellent and the Indians friendly.

Madame Mary Ferree, a persecuted Huguenot widow with six children, two of whom were married, after wandering for several years in the Palatinate and Holland, went to London for the purpose of contacting William Penn. This she did and Penn gave her a sizable tract of land, in what are today Lancaster and Chester counties, Pennsylvania, on which to make a settlement. With her family and followers Mrs. Ferree came to America in 1709 and chose to settle in the Pequea Valley of Lancaster County.

One of the descendants of the Ferree family was Ozias Ferree, the son of Jacob and Elizabeth Lefevre Ferree, who was born in Tyrone Township, Adams County, Pennsylvania, in 1818. ${ }^{11}$ The Ozias Ferree family moved from Adams County in 1863 to Panora, Iowa, where they settled permanently. ${ }^{12}$ Ozias Ferree died in $1909 .{ }^{13}$

Preparations for the Ferree Family's trip to Iowa were extensive. A six-horse team took the family possessions, which consisted of "14 W Boxes" and some smaller ones whose weight totalled 6,000 pounds, to Carlisle, the nearest point with which to connect with the "West RR". Mr. Ferree went along to secure the bill of lading and then they took the train to Harrisburg to secure railroad tickets." A discrepancy existed between the price which the agent of the Pennsylvania Railroad in Harrisburg quoted for the tickets and the advance information Mr. Ferree had secured by corresponding with

${ }^{11}$ History of Guthrie and Adair Counties, Iowa (Springfield, Continental, 1884), pp. 490f. On December 4, 1849, Mr. Ferree was married to Miss Sarah E. Lishy, a native of Codorus Township in York County, Pennsylvania (Ibid.).

${ }^{12}$ They had five sons and one daughter. The older sons, Carman LeFevre and Curtis Fenwick and the daughter, Sallie E., were born in Pennsylvania. The remaining sons, Cepedus Orlando, Centino Tellus, and Lishy LaVelle, were born in Iowa (History of Guthrie and Adair, p. 490). The name of Cepedus Orlando in reverse is that of the baseball player from Puerto Rico (This statement is made by Mrs. Cora Wyckoff of Des Moines, a granddaughter of Ozias Ferree, in a letter dated October
$31,1968)$.

${ }^{13}$ This article is based on a series of over one hundred letters which Mr. Ferree wrote during his years in Iowa to the family of his wife's cousin, Mrs. Daniel Leaman, in Lancaster, Pennsylvania. Mrs. Leaman was the grandmother of the author of this article. 
the Philadelphia office of the Railroad. Consequently they went to a "Brokers Office and bought a Coupon to the City for 50 cents and in the transaction saved $\$ 60.00 .{ }^{\prime 14}$

The record of Ozias Ferree's journey begins at Harrisburg, Pennsylvania, in April, 1863. The travellers went by train to Pittsburgh, stayed there for the night, then by rail to Chicago, where they stopped for two hours, next by train to the banks of the Mississippi, crossing the river on a steamer to Burlington, Iowa. They crossed the river at night and did not find the steamer to be a "flowery bed of ease." They remained a day in Burlington and then went by train to Mt. Pleasant. In Burlington they found business to be apparently good but there was saloon after saloon on nearly every street. Our voyager left his family in Mt. Pleasant and went by

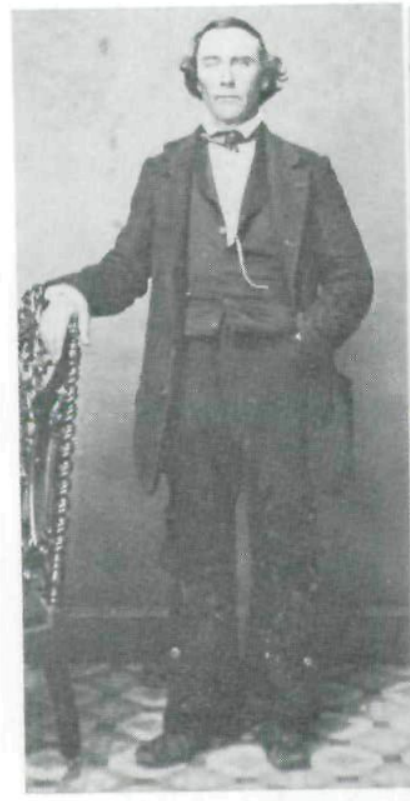

Courtesy of Dr. Leaman

Ozias Ferree

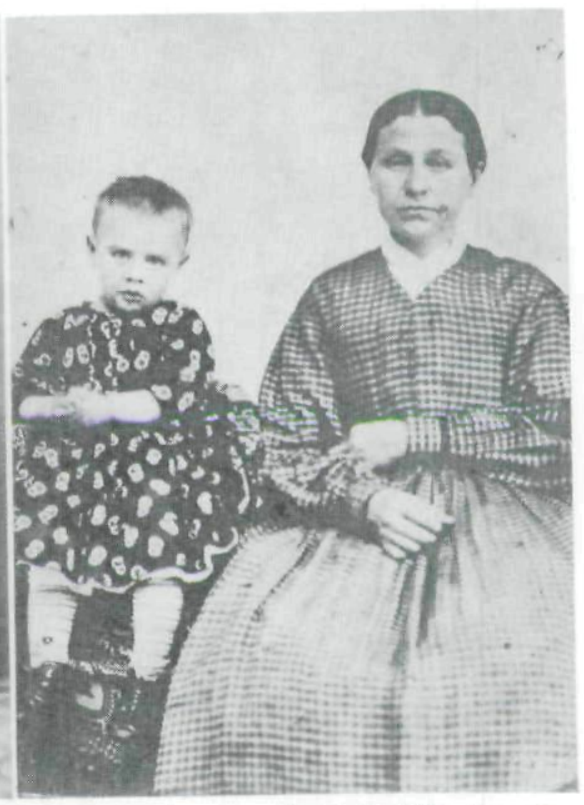

Courtesy of Dr. Leaman

Mrs. Ozias Ferree and daughter Sallie.

${ }^{14}$ Letters of Ozias Ferree written to the family of Mrs. Daniel Leaman between 1863-1909. He called his home "Friends Retreat" and always wrote his letters from that address. The current reference is to a letter written on January 16, 1906. (Hereafter these letters will be cited only by date). 
stage and train to Panora. He bought three hundred and thirty-five acres of land close to Panora and then returned to Mt. Pleasant for his family. Here he ordered their goods to be sent to Panora, bought a team of horses and a wagon, and started on the way to their final destination. He reports that they had comfortable quarters every night and that they made it a rule to start at sunrise and travel until eight or nine o'clock. They enjoyed the trip and reached Panora on June 16, 1863. They had traveled two hundred miles in eight days. The household goods which they had sent from Mt. Pleasant by wagon reached them in two weeks. ${ }^{15}$

Enough people left Lancaster and Adams Counties during these years to leave their mark on the State of Iowa. They did not go as a colony, planted by the government as were those planted by the Greek City State. Nor did they go as privately organized colonies as did many of the Pennsylvania Germans who went to Kansas. ${ }^{18}$ They went as individual families but they must assuredly have influenced each other's decisions to go. Mr. Ferree with his extensive and wide correspondence must have been quite a recruiter, probably in part because he continued to feel all of his life a strong attachment for the dear friends he had left in the East.

Some of Mr. Ferree's friends in the East preceded him to Iowa. While in Burlington they encountered a Philip Group, formerly a resident of Tyrone Township. Mr. Group told them of two other of their former neighbors who lived close by. When they reached Mt. Pleasant they went to the home of a cousin Peter Ferree Holtzinger, a Methodist preacher. Then they went to the home of Mrs. Ferree's brother who lived about fourteen miles from Panora. The father-in-law of Mrs. Ferree's brother was living in the area also, as was a former neighbor from Adams County, named Leahman (probably misspelled), and two Dunkard preachers. ${ }^{17}$

Some followed. In January, 1866, our narrator could boast of having several families from Adams County living close ${ }^{15}$ Jan. 16, 1906.

${ }^{16}$ See the article of George R. Beyer, "Pennsylvania Germans move to Kansas," Pennsylvania History, XXXII, No. 1 (January, 1965), pp. 25-48.

${ }^{17} \mathrm{Jan} .16,1906 . \mathrm{Mr}$. and Mrs. Ferree were members of the German Baptist or "Dunkard" church (Hist. of Guthrie and Adair), pp. $490 \mathrm{f}$. 
by, and that three more of their former neighbors were coming in the spring. Two of these were Neelys and the third a Mr. Plain; Mr. Plain was married to a Myers girl who had also been a neighbor of theirs at home. ${ }^{18}$ In the spring of 1880, Witmer L. Kindig visited the Ferrees and was trying to obtain a position in Des Moines. Cousin Christ Kindig and his wife were considering visiting Panora in the coming spring or summer. ${ }^{19}$

In April of 1882 Lee Fickes' father-in-law, Mr. Stum, and his son John visited Panora. Mr. Stum lived in Maytown, Pennsylvania, and the son in Marietta and they were considering moving to Iowa. ${ }^{20}$ Dan Brown, the postmaster at Panora, was raised in Strasburg. ${ }^{21}$ A. K. Myers and his wife, old friends and neighbors from Adams County, were living in Panora. ${ }^{22}$ In the fall of 1887 a company of Lancaster County friends from Lititz and Manheim, Bosslers, Brants, and Stomeroads, visited them. ${ }^{23}$ In the fall of 1890 Willis Hershey visited the Ferrees. ${ }^{24}$ And our recorder tells us that in 1890 Jacob Isenberger of Marietta had been living in the neighborhood for the past eight years. ${ }^{25}$

In 1866 our correspondent had said with pride that they had several families close by who had come from Adams County; twenty years later he could report that they could count twenty-five families of former acquaintances in their neighborhood who had come from Adams County. Two years later Mr. Ferree said: "We have a good and we think nice country, and good society, the majority being Pennsylvanians.

." ${ }^{26}$ Frederick Jackson Turner says that Pennsylvania was a notable contributor to Iowa, "taking a leading place among the Middle Atlantic states which York held elsewhere in the section." ${ }^{27}$

${ }^{18}$ Jan. 28, 1866.

${ }^{19}$ Mar. 12, 1880. See also the letter written on Oct. 5, 1880. "My mind frequently runs back to our youthful days. ... and my associations with your papa's family (this letter was written to Miss Sue Leaman, daughter of Daniel) and Christ (Kindig) and his family.... These two places were my headquarters of enjoyment. . . ."

${ }^{20}$ April 30, 1882.

${ }^{21}$ March 10, 1883.

${ }^{22}$ Sept. 12, 1886.

${ }^{23}$ Oct. 9, 1887.

${ }^{24}$ Dec. $7,1890$.

${ }^{25}$ Ibid.

${ }^{26}$ Ibid.

${ }^{27}$ United States, 1830-50, p. 274. 
Land furnished the relentless pull for these people from Adams and Lancaster Counties. These immigrants must have been an economic asset to the State of Iowa for in addition to developing the land, at least some of them brought hard cash with them. As early as $1886 \mathrm{Mr}$. Ferree bought a farm for "Brother Plain" from Adams County. For this farm, which consisted of 120 acres of prairie and 20 acres of timber, he paid $\$ 3800.00$. Mr. Plain said he could bring $\$ 20,000.00$ in "greenbacks" with him when he came. ${ }^{28}$ Mr. Ferree also, in 1883, purchased a farm, which was close to his own, for an old Maryland acquaintance. This farm comprised 320 acres and the cost was $\$ 14,000.00{ }^{29}$ These land prices compared very favorably with current ones in Lancaster County. Mr. Stum, who is mentioned above as having considered a move to Iowa, said he was offered $\$ 225.00$ an acre for his farm in Maytown. ${ }^{30} \mathrm{Mr}$. Ferree himself upon arrival in Panora bought 335 acres of land, including 15 acres of timberland. Only about 40 acres of this was under cultivation. ${ }^{31}$ Obviously the remainder was undeveloped land. ${ }^{32}$

Further evidence exists that monetary transactions of some dimensions were occurring: "I sold another farm for a friend East for $\$ 1100.00$, and have other little matters to collect for old friends in Pennsylvania, all some 8 or 9 hundred dollars. So you see my old friends put confidence in my honesty, have had nearly $\$ 6000.00$ cash of their money in my hand at one time. ..."3:3

Mr. Ferree prospered in Iowa. In 1877, fourteen years after his arrival, he built a "beautiful mansion", owned one hundred and seventy-five acres of land and had given each of his children a farm. ${ }^{34}$

${ }^{28} \mathrm{Jan} .28,1886$.

${ }^{29}$ Nov. $4,1883$.

${ }^{30}$ April 30, 1882.

${ }^{31}$ Jan. 16, 1906.

${ }^{32}$ Mrs. Cora Wyckoff, (ibid.) says that her grandfather bought the land from the government and paid $\$ 1.25$ an acre for it, so apparently he bought it under the provisions of the Homestead Act of 1862. Mrs. Wyckoff adds that the land is now worth $\$ 600.00$ an acre.

${ }^{33}$ Did some people in the East make investments in land in Iowa and then decide not to make the move after all?

${ }^{34}$ History of Guthrie and Adair, p. 491. 


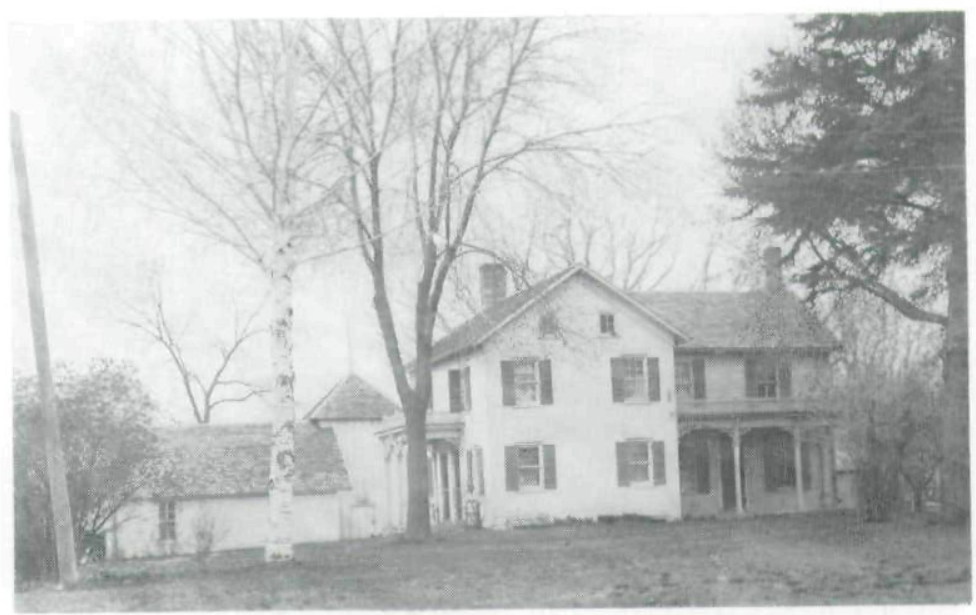

Courtesy of Mrs. Cora Wycoff, Des Moines

The original Ferree home $4 \frac{1}{2}$ miles north of Panora, lowarazed in 1959 .

Not only economic but also architectural influence was exerted by these people as they worked their way into their new country. Mr. Ferree and his family lived in a log cabin for several years and then built a house which was as nearly as possible like the one they had had at Gettysburg. This original house is pictured above. The left part of it is the part that was originally built. Another house was built later..$^{35}$

Coming to Iowa in 1863, Mr. Ferree clearly did not represent the first wave of settlers there. His own comment confirms this observation. Writing in 1868, he says: "The old pioneers are generally run out and we are getting a more solid working community,. . the first settlers in any new country generally make a living by hunting and trapping. . . There is now a class of citizens coming from the East who have the ability and the means to improve the country. ${ }^{36}$

As before 1863, growth and development after that date were remarkable. "When we came here there was a small strip of prairie north of us eighteen miles in length, without

${ }^{35}$ Mrs. Wyckoff, loc. cit.

${ }^{36}$ Feb. 7, 1868. 
a house in sight to cheer the wayfaring traveler. Now the little white cottages are sprinkled around like April blossoms, making the heart of the lonely traveler rejoice."

Twenty years later the report gives an even more graphic picture of development. "Imagine if you can that when we came here in 1863, buffalo, deers, (sic) wolves, badgers, rattlesnakes, wildcats roamed at large over these prairies - now nearly all have disappeared." ${ }^{38}$ Further, "Families living ten miles away we called neighbors and treated them as such. North it was 18 miles to the first house, East 10 miles, Northwest 35 miles, South and Southwest three-fourths of a mile. And now frame buildings are on every section and will average more." ${ }^{39}$

Mr. Ferree settled in what is now Panora in Cass Township, Guthrie County. The county has been described in glowing terms, being called one of the best grazing and farming counties in the state. ${ }^{40}$ And, "besides possessing mineral wealth, a soil unexcelled in fertility, timber in moderate supply and water power abundant for all manufacturing purposes, it has fine grazing lands for stock raising and scenery of unsurpassed beauty." ${ }^{\prime 4}$ A further description tells us that corn had always been the great cereal of this section of the country but that wheat, rye, oats and other small grains flourish with "surprising fecundity and are noted for the excellent grade; wheat seldom falling below No. 1 quality." General or mixed farming was, however, usual, stockraising being important in the agricultural pursuits of the inhabitants.

Cass Township, too, appears to have had its virtues, and its beginning history is not without interest. In 1849 two white men came to what later became Cass Township and decided to stay. ${ }^{43}$ The first land was broken in the spring

${ }^{37}$ Jan. 17, 1871. His report was accurate, for, "Ozias Ferree . . . locating in North Cass Township, in Section 17, where the country north was one vast prairie" (Hist. of Guthrie and Adair, p. 490).

${ }^{38}$ Dec. 7, 1890.

${ }^{39}$ Ibid.

${ }^{40}$ Sadie Maxwell, Centennial History of Guthrie County, Iowa (Des Moines, Carter and Hussey and Curl, 1876), pp. 12 f.

${ }^{41}$ Maxwell, p. 12.

${ }^{42} \mathrm{Hist}$. of Guthrie and Adair, p. 419.

${ }^{43}$ Ibid., p. 474. 
of 1850 and the first log cabin is said to have been erected in 1850 in what later became Panora. ${ }^{44}$ Cass Township, one of the oldest in Guthrie County, is described with romantic eloquence as being by far the loveliest appearing of any section of Guthrie County. Further, "With but slight exceptions, the surface consists of gently rolling prairies that stretch in undulations far away, and the view in spring and summer particularly is beautiful in the extreme. The lovely fields of grass stretching before the eye, dotted here and there with innumerable clumps and groves of natural and artificial timber, the pellucid streams that glow with silvery sheen across its surface, all have a part in making up one of the most beautiful landscapes that the eye of man hath seen." ${ }^{45}$ And there is more, "Cass Township is well watered by numerous streams that meander across the fertile acres. . . The soil is rich, black, sandy loam. . . . and for general fecundity and quickness of growth, has no equal on earth."

Mr. Ferree's description of life in his area of Iowa during these years is remarkably accurate. Comparison with other contemporary writings attests to this fact. While some of the things he tells us are recorded elsewhere, he has made a valuable contribution to recorded history of the age. As one reads the accounts of the life around Ferree and of his daily activities, one realizes before long that here was a man who played a vital role in his community. He was a modest man but nonetheless his own account tells us better than anyone else could what this role was: "Not to brag but our place is called headquarters in this neighborhood. . . Many times for a week in succession, (I) scarcely enjoy a single meal in the presence of my family alone. Some come to borrow money, others flour, others tools of different kinds, others returning borrowed articles, travelers asking information, speculators looking up land, travelers staying overnight, teamsters, etc., men and little boys looking after stock, shepherds calling for a drink, and 'school marms' calling for orders to lift their wages. . . I I have to accommodate often

${ }^{44}$ Ibid., p. 493.

${ }^{45}$ Ibid., p. 473.

${ }^{46}$ Hist. of Guthrie and Adair, p. 473. 
from ten to a dozen strangers overnight and several teams and as many as 15 travelers at a time for dinner, also have a mail distributing office. You can imagine the rest., ${ }^{47}$ And he had been in Iowa less than three years at the time this was written! The home of the hospitable Mr. Ferree must have been just what he chose to call it: Friends Retreat.

In the section on Cass Township in the History of Guthrie and Adair Counties we find this statement: "Coming in at a later date were many individuals who, though not to be reckoned among early settlers, still deserve mention because they were prominent in the development of this locality. Herewith are presented the names of those who may justly be ranked among the enterprising and more representative men of Cass. ${ }^{38}-\mathrm{Mr}$. Ferree is mentioned, a biographical statement is also included.

In her early days Iowa suffered irreparable damage from grasshoppers. The accounts of the invasions from them are so extravagant that they cause one, in the words of one writer, to be "apt to regard the story of even an eye-witness incredible." Mr. Ferree's account adds to the memorabilia about this plague and in so doing helps to eliminate the credibility gap, should there be one.

It appears that the grasshoppers did not arrive in Iowa prior to 1833. The first serious raid occurred in July, 1864, when the region in the vicinity of Sioux City suffered severely. The state also played host to these invaders in succeeding years, the greatest being those of $1867,1873,1874$, and $1876 .{ }^{49}$ Mr. Ferree's description apparently ties in for the most part with the 1867 visitation.

Our reporter tells us that they came in September of 1867 and since this was late in the season they did not do much damage, although they did eat the blades and a good portion of the husks off the corn and destroyed all the fall vegetables. Having deposited their eggs shortly after they came, they disappeared and it was believed that they had

${ }^{47} \operatorname{Jan} .28,1866$.

${ }^{48}$ P. 490.

${ }^{49}$ John E. Briggs, "The grasshopper plagues in Iowa," Iowa Journal of History and Politics, XIII (1915), p. 361. A full history of the years and places of the plague is given by Briggs. 
all died during the winter. ${ }^{50}$

But in the following Spring the eggs began to hatch and they continued hatching until June. By that time many of the older ones could fly. Our narrator portrays them as being "so thick in the air as almost to obscure the sun. They continued lighting for ten days and the truth was that the earth was literally covered by them. I believe that in many places there was a half bushel of them on a square yard of ground." ${ }^{51}$ They had boundless appetities. Clearly apprehensive, our writer notes that they sowed only about forty bushels of wheat in the latter part of March, 1868. They "sowed 2 bushels to the acre and harvested 200 bushels, this being less than one-third of a crop." ${ }^{\prime 2}$ They watched helplessly as their own crops and those of their neighbors were destroyed as the grasshoppers relentlessly ate their way through the fields. "Hundreds of acres were sown in wheat, with never a reaper entering the field, many fields being as bare of vegetation as the public road."

Further, the grasshoppers "destroyed nearly one-half of the corn crop. . . they attacked it when it was in tassel, eating it off at the ground. When a stalk would fall ten thousand of them (more or less) would hop onto it and eat it quicker than 'Pady did the hot apple pudding!" ${ }^{54}$ Although they ate everything in sight, the grasshoppers did show a preference for the important grain crops, particularly wheat. Mr. Ferree tells us, that they did not, however, appear to have dainty stomachs and that they were not discriminating for they would devour a patch of camomile, dog fennel or smart weed with apparent relish. ${ }^{55}$ Vegetables, too, were a temptation to them. "We only raised 75 bushels of potatoes and a few turnips and perhaps twenty small heads of cabbage." Apparently the farmers and the grasshoppers were in a running fight, for "we planted cabbage six times and each time they ate it. We had enough onions set out to make 20 or 30 bushels and got about one bushel of little ill-shaped

\footnotetext{
${ }^{50}$ Feb. 1, 1869.

${ }^{51}$ Feb. 1, 1869.

${ }^{52} \mathrm{Feb}, 1,1869$

${ }^{55}$ Ibid. "One writer testifies that they will feed upon the dry bark of trees," Briggs, p. 353.
} 
roots that looked as if they had grown out of the crevice in a rock. ...." ${ }^{n 6}$

Comparing the grasshoppers with those he had seen formerly in Eastern Pennsylvania, Mr. Ferree records that they were not similar, the Iowa variety being a species of locust. They were, in fact, Melanoplus spretus, known as Rocky Mountain locust but the frontiersmen contemptuously called them grasshoppers. ${ }^{57}$

The grasshoppers covered widespread but clearly defined areas. In 1873 "they spread in flocks over a territory taking Fort Dodge for the southeast corner, running north into Minnesota, and how far west, I do not know. At no time did it extend east of Ames. Only comparatively few settled in Webster County and these in small swarms in the northern townships along the Des Moines River." ${ }^{n 8}$ Mr. Ferree's Guthrie County was clearly included in the 1867 en masse attack and destruction.

The damage from this pest was worse in the less settled counties but the experience must have been traumatic for everyone and devastating for those who did not have sufficient resources to carry them through these unproductive years. The State Legislature did not do anything to ameliorate the sufferings of those who were destitute, but clothing and produce from other parts of Iowa and from other states, even as far away as New England, were sent in sizable quantities. In spite of these contributions, however, many people gave up and left Iowa. ${ }^{59}$

For those who remained, seeds to plant new crops were scarce. The State Legislature made an appropriation in 1874 to buy seed for farmers in the stricken areas for the ensuing

${ }^{56}$ Feb. 1, 1869.

${ }^{57}$ Ibid. See also Briggs, pp. 350ff.

${ }^{58}$ Cyrus C. Carpenter, "The grasshopper invasion," Annals of Iowa, Vol. 4, No. 6 ( July 1900), pp. 437-439.

${ }^{59}$ Carpenter, p. 445. Trenary, Walter N., "The Minnesota legislator and the grasshopper, 1873-77," Minnesota History, 36 (1958-59), 54ff., gives an excellent account of the grasshopper damage in Minnesota and of the attempt on the part of the state legislature to do something about it. 
season. ${ }^{60}$ Mr. Ferree, in his earlier letters, occasionally asks his Lancaster relatives for seeds but in doing so he is not facing the hard facts of life but rather asking for flower and vegetable seeds. For example: "Sarah (Mrs. Ferree) asks Mrs. Leaman to send her some early radish seed and any flower seed she may have to spare such as 'pinks', Queen Margarets or dollar flowers and a few cabbage seeds." $\mathrm{He}$ (Mr. Ferree) has some doubts about the integrity of the local seed merchants, "we can get seeds in the stores but we always fail to raise anything believing the seed to be injured by age or intentionally." ${ }^{" 2}$ He made a trip to Lancaster during one of his early years and there is reason to believe that he bought a good deal of seed at that time. He said in one of his later letters, "I have saved about twenty bushel ears of that corn brought from your place and intend planting all of it." ${ }^{\text {"3 }} \mathrm{He}$ liked to do a little experimenting also for on one occasion he wrote: "If you please send us some of your seed leaf tobacco seed as we should like to try to raise some," and then he adds, "we will send you some squash seeds, of the California variety, also a few grains of spring wheat of our own raising. ${ }^{64}$

Not only grasshoppers but chinch bugs were rampant and ruinous. Our recorder writes in 1891 that very little wheat was being sown in any part of Iowa as the chinch had become so numerous that they almost completely destroyed the crops and that the farmers had concluded to "starve out the pest by not sowing any wheat for a few years." ${ }^{\circ 5}$

Game was plentiful. Our writer reports seeing thousands of prairie chickens "in the last two weeks and rabbits are

${ }^{60}$ Carpenter, p. 445. Carpenter considers there "never was a better investment than this appropriation. It undoubtedly determined a good many to stick to their farms who, without this small encouragement, would have given up the unequal contest, sold their farms at a nominal price and moved away."

$\begin{array}{ll}{ }^{61} \text { Feb. 1, 1869. } & { }^{63} \text { Jan. 14, } 1874 . \\ { }^{62} \text { Ibid. } & { }^{64} \text { Jan. 31, } 1865 .\end{array}$

${ }^{65}$ March 16, 1891. See also Swisher, J. A., "Chinch bugs rampant," The Palimpsest, XVI (July, 1935), pp. 210ff. "Chinch bug infestations have been frequent in Iowa since 1846 ... Greatest damages were in 1887 and 1934, in each of which years an estimated loss of more than $\$ 25,000,000.00$ occurred. During years between the epidemics, they have not been entirely absent." 
here by the thousand." ${ }^{66}$ To illustrate how easily game could be caught, our narrator reports, "In order that you may have an idea of the wild fowl that is here, I will state that Carman shot 75 ducks in twelve shots inside three hours. They lay so thick on the ground that he could not count them." ${ }^{{ }^{77}}$ Further, "Carman, our oldest son, went to a small lake (some four miles from here). There was open water in places where the ducks were bunched. He shot twelve times, gathered up the ducks and came home for a wagon and brought home 72. A neighbor who was on the opposite side of the lake said he picked up 25 ducks that Carman had killed and had failed to find."

Our farmer friend complains about the prairie chickens being very hard on the cornfields in the fall, "I think they ate two hundred bushels for us last fall." ${ }^{\prime 9} \mathrm{He}$ also found them hard on newly sown wheat, "I sowed some wheat for the first time this season yesterday. . . if it does not come up pretty soon the prairie chickens will take all of it." ${ }^{\prime 0}$

The grasshoppers ate the wheat and corn and the prairie chickens ate them too. But, the prairie chickens also ate the grasshoppers, being among their most destructive enemies. The number of prairie chickens and other fowl killed by the farmers for their own use was probably not great enough to have any noticeable effect on the immunity of the grasshoppers. But they were also killed for commercial purposes. Briggs says that uncontrolled slaughter of millions of prairie chickens and quail was responsible for the multiplication of the grasshoppers. He says it was reported that the Chicago market in prairie chickens and quail was so flooded at times that the produce spoiled. After being condemned by the health authorities, as many as ten thousand of them were fed to hogs in a single day. ${ }^{71}$

Less commonplace was an occasional buffalo that strayed

\footnotetext{
${ }^{66}$ Easter Sunday, March 27. No year given but it was during the Civil War.

${ }^{67}$ Dec. 22, 1881.

${ }^{68}$ Jan. 16, 1906.

${ }^{69}$ Easter Sunday, March 27. No year given.

${ }^{70}$ Ibid.

${ }^{71}$ P. 351.
} 
into the area. ${ }^{72}$ One might ask whether the Fourth of July attracted or disturbed them. At any rate, on two successive Fourths, in 1863 and 1864, a single buffalo wandered into the vicinity of Panora. Chasing them was exciting but hazardous and not designed for the faint of heart. One neighbor of Mr. Ferree had a savage bulldog, which in the course of the chase of one of the buffaloes, "nosed that animal several times, throwing him down, and in order to protect his dog, he (the neighbor) got too close to the enraged animal, which made a lunge at his horse making a gash several inches in its thigh." ${ }^{73}$ Our narrator adds that there were at that time two small lots of buffalo in the vicinity, from fifteen to seventeen in a herd. Buffalo meat is described as being "tender as veal and flavored like beef." ${ }^{.4}$ It is not surprising that some buffalo appeared for there were still plenty of them in the West. In 1869 a train on the Kansas-Pacific Railroad was held up for eight hours by buffalo. These, too, were the years when the Union Pacific Railroad was being built and Colonel William F. Cody earned his title of "Buffalo Bill" by killing over four thousand in one and one-half years. ${ }^{75}$

Less amiable visitors came around also. "Through the snow and cold, weather wolves are becoming numerous and bold. We saw three at one time near our buildings. They seem to have a fondness for pigs, poultry, calves and sheep," but he adds reassuringly, "they they seldom attack a person unless the pack are numerous and famished." ${ }^{\prime 76}$

As early as 1890 corn appears to have been the most important crop. "The corn is our standard grain but it is not as good as common (this year), it being too wet and cold in the spring and too dry through August and September. Yet I think our best crop on dry land will make from 50 to

\footnotetext{
${ }^{72}$ Here we have an example of Mr. Ferree's accurate reporting, for we read: "and single buffaloes roamed at will" (Hist. of Guthrie and Adair, p. 490 ).

${ }^{73}$ Jan. 16, 1906.

${ }^{74}$ Ibid.

${ }^{75}$ Ralph Volney Harlow, The growth of the United States (New York, Holt, 1932), p. 575.

${ }^{76}$ Jan. 22, 1886. See also Petersen, Wm. J., "Wolves in Iowa," Iowa Journal of History and Politics, 38 (January, 1940), 50-93.
} 
60 bushels per acre. . . . We have planted 180 acres in corn in one season but this year all of our farms have planted only 120 acres." ${ }^{\prime \prime 7}$ Under these circumstances it is not surprising that the price of wheat was high compared with that of corn. $^{78}$

There are frequent references in the letters to oats; this may mean that they did not have any trouble raising it, and the price was low. ${ }^{79}$ Flax, too, was grown: "It is not uncommon to see from 80 to 100 acres of flax on one farm." ${ }^{80}$

Potatoes were in good supply, "very fine and plentiful." ${ }_{11}$ Sweet potatoes also did well: "We had 35 bushels of sweet potatoes, very fine for a dry season, by weighing several in a lot I found they average 3 pounds, 10 ounces apiece and French squashes from 50 to 142 pounds per piece." ${ }^{\$ 2}$ Melons were plentiful and sizable: "We had wagon loads of them, very fine ones, the largest weighing 30 pounds apiece. ${ }^{83}$ And again he reports that they had melons that weighed 35 pounds and cantaloupes weighing 18 pounds. ${ }^{84}$ Hazel nuts and walnuts can be had by the wagon load." ${ }^{85}$ Apples, too, were grown. Some local pride is in evidence as we read: "It is said that this county has more apples than any county in the state." ${ }^{\prime 6}$

To try out the possibilities of raising tobacco would be but natural for a former farmer in eastern Pennsylvania. "Tobacco farming has not become a specialty here yet on account of our stringent laws but I raise a little almost every season and we see occasional small lots growing. One of our neighbors is building a large tobacco barn and intends cultivating the 'weed' more extensively. I have raised several hundred pounds in a season and cut it by the middle of August. Lancaster County men say they never saw a better article. ${ }^{" 87}$ And then comes a warning, jocose or otherwise:

${ }^{77}$ Oct. $30,1882$.

${ }^{78}$ In January, 1889, he quotes corn as selling for 18 to 20 cents per bushel, and wheat for 90 cents to $\$ 1.00$.

${ }^{79}$ January, 1889,18 to 20 cents.

${ }^{80}$ Oct. $30,1882$.

${ }^{81}$ Ibid.

${ }^{82}$ Oct. 15,1880

${ }^{83}$ Nov. 21, 1893.

${ }^{84} \mathrm{Ibid}$

${ }^{85}$ Jan. 17, 1888.

${ }^{86}$ Ibid.

${ }^{87}$ April 30, 1882. 
"If raising it in Iowa becomes an industry it will injure your Eastern markets. Our land needs no fertilization and scarcely a worm is to be seen." 88

Mr. Ferree describes in some detail the method of harvesting the farm crops: "When our wheat and oats gets (sic) too ripe to bind we use a 'header', it cuts a swath 11 feet wide and seven men and ten horses will cut and stack 40 acres a day, some machines cut 25 feet wide and harvest from 70 to 80 acres a day." ${ }^{89}$ But mechanization was on its way. The twine binding harvesters and sulky plow were coming into general use. Our narrator speaks disparagingly of the sulky plow which he calls the laxy man's hobby. "We had two of them but I don't like them as they are hard on the teams and require three horses for a single plow and four horses for a double one to cut two furrows." ${ }^{\text {"o }}$

In describing threshing procedures, he tells us that: "We. . . . threshed 35 acres of oats on shock in 5 hours. One team of three horses will cut and bunch from 12 to 15 acres of clover seed and thresh and hull in the same operation from 80 to 100 bushels in a day if the seed is good. We only cut 11 acres, making over 33 bushels and hulled in 4 hours. . . . We shell 3000 bushels of corn in a day, by steam power."

Mr. Ferree made some effort to introduce farm equipment from Lancaster County into Iowa, expressing a wish for one of the Lancaster County wheat fans, saying that he had never seen a mill in the area that was worth the room it occupied. The fan he had in mind was, he thought, "called Baumgartner's Patent, and if you please, I should be under lasting obligation if, when you go to the city, you would find out if they are still manufactured there and also if they are manufactured at any point nearer to this than Lancaster, $\mathrm{Pa}$. And. . . if you have the time to spare, inquire what are the cash rates for a No. 2 Mill, and the probable cost of freight to New Jefferson, Green County, Iowa. If the fans were introduced here and the price reasonable, I think I could sell

${ }^{88}$ Oct. $30,1882$.

${ }^{89}$ April 30, 1882.

${ }^{90}$ Ibid.

${ }^{91}$ Nov. 21, 1893. 
them by the dozen...." ${ }^{22}$

Apparently there was active response regarding the fan. In the spring of the same year he writes his cousin: "First of all I want to thank you for the trouble you took in my behalf in regard to those wheat fans. I received from Mr. Kelly his price list and circular, he also offering me the agency, which I notified him I would be compelled to decline at present expecting to write him again some time in the future. I have an idea that the freight to this point would cost half as much as the fan. Yet one of my neighbors says he will take one irrespective of price if I send him one.",93

Woodland did not exist in great quantity, the natural growth of trees being limited to those along the streams. Groves of trees were planted, they furnished protection to buildings and orchards from storms and would in time supply a limited amount of firewood. But the insufficiency of timber for fuel was abundantly compensated for in the coal fields which underlaid many parts of the county. ${ }^{94}$ Many coal mines were opened throughout the county, the first one being that of J. T. Frazier in 1858, three and one-half miles southeast of Panora. The cost of coal, delivered, at that time was ten cents per bushel. In 1865 a most inferior quality cost thirty cents a bushel. ${ }^{95}$

Coal mining was seen as an independent future industry in Guthrie County. An important fact in its development was that it lay in the upper coal measure. It is reported that coal of a splendid quality had been placed on the market and that since the whole of Guthrie County was underlaid by this invaluable fuel it would be only a question of time until Guthrie County would take its place among the foremost coal-producing counties of the state. ${ }^{96}$

Natural gas was also found in the area and it was used for illuminating and heating. Many persons also used it to

\footnotetext{
${ }^{92} \mathrm{Jan} .14,1874$. This letter was written to Daniel Leaman.

${ }^{93}$ April $20,1874$.

${ }^{94}$ Maxwell, pp. 9f.

${ }^{95}$ Ibid.

${ }^{96}$ Past and present of Guthrie County, p. 44.
} 
light their yards at night. ${ }^{97}$ Other neighbors, apparently preoccupied with their farming duties during the summer, planned to develop during the winter the gas they had found. Harendon, a new town nine miles north of Panora, is reported by Mr. Ferree as having had several gas wells with consequent rapid growth in manufacturing. ${ }^{98}$. These discoveries were not unaccompanied by dramatic episodes. One neighbor in boring down an old well at a depth of fity feet struck a vein of natural gas. Getting out as soon as possible, one of the curious workmen struck a match to light a lantern in order that they could take a look into the well. The gas ignited from the match and blazed up sixty feet into the air, burning two of the men quite seriously. But since the well was near the barn and a pond of water was nearby, they drained the water into the well. But the problem now was to get rid of the gas. They pried the wall into the well with poles to a depth of fifteen feet but the gas continued to escape. ${ }^{99}$

The water supply was good. Many artesian wells existed in Cass Township, some of them throwing water thirty feet above the surface. ${ }^{100}$ The summer of 1887 was an unnaturally dry one and many wells failed. Mr. Ferree reports that his family was among the more fortunate, having plenty of water and also a supply for their less favored neighbors. Many persons, he tells us, were compelled to bore and dig deeper for water. $^{101}$ Technical improvements helped further to establish a good water supply. By 1882 nearly all the wells were "bored by augurs from six inches to three feet in diameter and many of those from 100 to 300 feet deep flow a constant stream." ${ }^{102}$ Depth of the soil was also noted in connection with boring wells for frequently it was necessary to bore from 200 to 400 feet before striking rock. ${ }^{103}$

The usual diseases of the time were prevalent and cast their shadow of sorrow as measles, diptheria and scarlet fever took their toll among the children. Our reporter tells us that "measles have prevailed to an alarming extent during the winter and up to the present and many children have

${ }^{97}$ October 9, 1887.

${ }^{98}$ Ibid.

${ }^{99}$ Sept. 12, 1886.

${ }^{100}$ Ibid.

${ }^{101}$ Oct. $9,1887$.

${ }^{102}$ April 30, 1882.

${ }^{103}$ Oct. 9, 1887. 
died. Our youngest boy has not taken them yet." ${ }^{104}$ And again in the spring, eight years later, we read that "diptheria and scarlet fever have been prevalent and many little caskets have been consigned to Mother Earth. There have been no cases of smallpox in this community but the doctors have had a busy time vaccinating." ${ }^{\prime 105}$ And the following year: "Scarlet fever and diptheria have been raging to an alarming extent and many children have died and a good many adults also. Quite a number of our schools have been closed on that account and the end is not yet reached." " A few years later the report becomes sadly personal: "Curtis's oldest daughter ( six years old) died of Membraneous croup. . . . Diptheria, measles, and scarlet fever are raging in this county, one of our distant neighbors has buried two in the past two weeks from diptheria and our schools are closing, teachers and children being sick." ${ }^{107}$

Mr. Ferree kept in touch with events and folks back home by reading the Lancaster Examiner and the Gettysburg Gazette weekly. He reports having subscribed in one year to five daily papers and to frequently receiving from twentyfive to thirty papers weekly, including papers from almost every state in the Union, from London, Glasgow, and sometimes a Dutch one. ${ }^{108}$ He informed his family in Lancaster that they in Iowa received foreign and domestic news as soon as they for they lived right on the telegraph line from New York to San Francisco, ${ }^{109}$ and they received mail twice a day when the roads were good. ${ }^{110}$ Then came a lament that has a familiar ring: we get more papers than time permits us to read. Did he, like some of us, fear the danger of sinking in a sea of printed matter never to be heard of again?

There was, indeed, no dearth of local publications. "Des Moines has 52 papers and periodicals and many dailies and

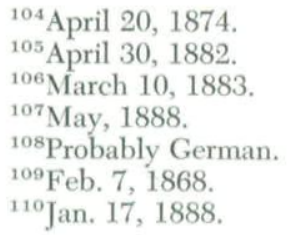


about every village in Guthrie County supports a paper." ${ }^{\prime 11}$

The prospect of having railroads come to Iowa was a thrilling one. Their appearance at the western border of Illinois was enough to fire the imagination of the people in Iowa. That the railroad would soon come either to Galena or Savanna was undoubted in 1851, and it was predicted that the completion of the road would revolutionize the trade of the country bordering on the Mississippi above Davenport and the effect on the interior would be inestimable. The direction of trade would also shift from south to east, that is, the produce of Iowa would go east and find markets and from the east would come her merchandise. ${ }^{112}$ And imagination ran farther: "Among the many enterprises projected in our day none possesses more intrinsic importance than. . . .the Council Bluffs Railroad. The road is designed to form a link in the great western railroad that will, at no distant day, pass beyond the Rocky Mountains and meet the commerce of Asia on the shores of the Pacific. ${ }^{113}$ Then came action within Iowa herself.

On May 15, 1856, the Federal Government passed an act granting land to the State of Iowa for the purpose of building a railroad from Burlington to the mouth of the Platte River; from Davenport, by way of Iowa City and Fort Des Moines to Council Bluffs; from Lyons City as nearly as practicable, on the 42nd parallel of latitude to the Missouri River at a point as near as practicable to Sioux City. This constituted a four million acre grant of land by the Federal Government. In days when we talk casually in terms of billions of dollers, this grant may appear to be minimal but it was estimated that it was probably worth $\$ 40$ an acre or $\$ 160,000,000$. The state legislature accepted the offer with alacrity. One month later, on July 14, 1856, at a special session, this legislative body accepted the federal grant. It took the

${ }^{111}$ October 9, 1887. That there were many publications in the midWest at this time is supported by Turner who found subscriptions to newspapers high, he also reflects favorably on their quality (The frontier in American history, New York, Holt, 1920, p. 353 ).

${ }^{112}$ Bellevue Democrat, Oct. 29, 1851.

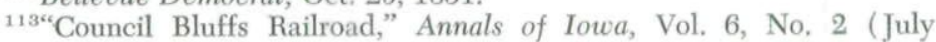
$1903)$, P. 137. 
General Assembly of Iowa less than ten days to reach a decision and it is refreshing to note that, according to one account, no conflict of interest was involved for it is reported that as far as was known no member of the General Assembly profited, or attempted to profit, by the legislative action. ${ }^{114}$

Criticism of railroad activity was not unknown in this period. In addition there was the usual conflict between those who spoke for corporate wealth and the rights of private capital on the one hand and those who spoke for the public interest on the other. ${ }^{115}$

Panora was for many years without railroad facilities and was hence much behind the cities in the neighboring county of Dallas. It was not until 1874 that Mr. Ferree could write that "their contemplated railroad seemed to be reviving again." In December of 1879 the Wabash, St. Louis and Pacific Railroad did build a narrow gauge road to Panora, connecting it directly with the state capitol and thereby with the markets of Chicago and elsewhere. ${ }^{116}$ Mr. Ferree announced this jubilantly, adding that it was reputed to be the best paying road in the state. Panora responded to its new status by "beginning to look like a city, having fine brick blocks, first class stores of all kinds, and many manufacturing establishments." 117

But greater things were looming on the horizon and what excitement was in the air for we are told that in October, 1880 , two railroad companies were surveying in Guthrie County and that the road to Panora was to be extended to Sioux City. Any side of the tracks was the right side for we are told with pride that the surveyors ran along our East line, one-half mile from our buildings. The surveyors were at the Ferree house for dinner on two days. The second line was to run west, six miles north of Panora. In addition there was to be a branch of the Rock Island terminating at Guthrie

${ }^{114}$ Hon. Peter A. Day, "Recollections of the Old Capitol and the New," ANNALS OF IOWA, Vol. 7, No. 2 (July 1905), p. 86.

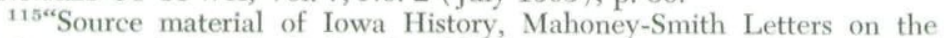
Dubuque and Pacific Railroad, 1857," Iowa Journal of History And Politics, Oct. 1856, pp. 335f.

${ }^{116}$ Hist. of Guthrie and Adair, p. 507.

${ }^{117}$ Oct. $15,1880$. 
Center. This would give Panora three railroads, the farthest being seven miles distant. ${ }^{118}$

In the early summer of the following year our correspondent could tell us the railroads were progressing rapidly. The one closest to his home was three-quarters of a mile distant, another was five miles north, and by the following summer he expected one to be built three-quarters of a mile west of their buildings. The prospect for better markets was exhilarating. ${ }^{119}$ We are told in December, 1881, that there were six railroads within a day's drive and return of Panora and that this city was developing as a business center with very fine buildings whose prices ranged from $\$ 5,000$ to $\$ 16,000$ each.

Pride in the railroads was obvious. Speaking of a cousin who lived in Davenport, Mr. Ferree said the distance from Panora was over two hundred miles but since they had the railroad it was only a half day's journey.

A description of these energetic and persistent people, as they went from a settled home in a developed area of the country to an undeveloped one a long distance away, is of interest, but only if one sees them as a part of a larger movement do they acquire significance. The westward expansion movement that filled a continent, as wave after wave rolled across it, was majestic. The broad sweep of this movement tempts one to think of it in general terms, but the story of the Ferree family exemplifies it in miniature, and this was actually the way the West was filled. That Pennsylvania was a seedbed for the West has long been recognized, and these migrants from Lancaster and Adams counties are eminent examples of the manner in which the eastern part of the state spread its influence and culture to one part of the West. It is quite possible that Mr. Ferree and his friends did not conceive of themselves as part of the larger westward expansion movement but their letters attest to the fact that they were an important part of it. These letters also furnish a wealth of detail that enriches our information about this stupendous march across the continent.

${ }^{118}$ Ibid.

${ }^{119}$ June 11, 1881. 
Copyright of Annals of Iowa is the property of State of Iowa, by \& through the State Historical Society of Iowa and its content may not be copied or emailed to multiple sites or posted to a listserv without the copyright holder's express written permission. However, users may print, download, or email articles for individual use. 